\title{
Chronology of the Life and Career of Charles Olson
}

1910 Born Charles John Olson, December 27, in Worcester, Mass., son of Charles (Karl) Joseph Olson, a letter-carrier, and Mary Theresa (Hines) Olson; raised in a tenement on Norman Avenue in Worcester.

ca. 1915 Begins summers at Gloucester with father and mother. By at least 1923 the family regularly occupied "Oceanwood" cottage on Stage Fort Avenue each summer, in what was known as Barrett's camp, above Stage Fort Park.

1917-24 Attends Abbott Street Grammar School, Worcester.

1924-28 Attends Classical High School, Worcester, where he is an honor student, captain of the debating team, and president of his class.

1928 Wins Northeast regional oratory championship that spring, and takes third place (despite bad cold) in National Oratorical Contest, Washington. D.C., May 26. Ten-week tour of Europe as a prize. Enters Wesleyan University, Middletown, Conn., upon return; while at Wesleyan he is an honor student (Phi Beta Kappa), editorial writer for the school newspaper, goalie on the soccer team, actor, orator, and candidate for a Rhodes scholarship.

1929 Attends the Gloucester School of the Little Theatre for the summer, performing in several productions.

1930 Works briefly for the C \& R Construction Company on a reservoir project in Gloucester that July (see Maximus I, 21).

1931 Substitute carrier for the Post Office in Gloucester that summer and subsequent summers through 1934.

1932 Receives BA from Wesleyan in June. Performs with the Moorland Players in Gloucester that summer. Continues studies at Wesleyan in the fall, with a course (as an Olin Fellow in English) in American literature at Yale.

1933 Receives MA in English from Wesleyan in June, with thesis "The Growth of Herman Melville, Prose Writer and Poetic Thinker." Continues at Wesleyan that fall; begins search 
for Melville's library, going to Cambridge, Mass., for research among the Melville family papers, and by the beginning of 1934 has made enough progress for his teacher, Wilbert Snow, to arrange for an award of an Olin Fellowship in Economics to continue the work.

1934-36 Instructor of English at Clark University, Worcester. His father dies in August 1935 at 53 of a cerebral hemorrhage.

1936 Sails July 7 aboard the schooner Doris M. Hawes on a threeweek voyage for swordfish on Brown's Bank. Meets Edward Dahlberg early August in Gloucester. Enters Harvard University in the fall as a graduate student and assistant in English and American literature. Courses taken at Harvard will include Frederick Merk's "The Western Movement."

1937 Returns to Harvard as an instructor and tutor (staff of John Winthrop House) there and at Radcliffe.

1938 July 1, first trip west, hitchhiking from Kansas City to San Francisco; returns leisurely by Greyhound (by August 14). Continues at Harvard in the fall as counselor in American Civilization (Winthrop House); course work for Ph.D. completed by the spring of 1939 , first of three candidates in American Civilization program. "Lear and Moby-Dick" published with the help of Dahlberg, who selected it from a long paper written for F. O. Matthiessen's class. Living in Boston on Charles Street.

$1939 \quad$ Awarded first Guggenheim Fellowship in March for studies in Melville. Spends fall and winter with his mother in Gloucester; writes a first version of a book on Melville, which Dahlberg advises against publishing.

1940 Writes his first poems and an essay on myth in February while still at Gloucester; leaves for New York the next day. Meets the painter Corrado Cagli in May, and Constance Wilcock, who is to be his wife, the same month. Returns to Gloucester in June.

1941 October 1940 to April, living at 86 Christopher Street in Greenwich Village. May to July, publicity director for the American Civil Liberties Union. Beginning in November, serves as chief of the Foreign Language Information Service, Common Council for American Unity, New York (to September 1942).

1942-44 In September, begins work for the Office of War Information (OWI) in Washington; will serve as Associate Chief, 
Foreign Language Division, until he resigns in protest, May 1944. Only publication for the government is a pamphlet in collaboration with Ben Shahn, Spanish Speaking Americans in the War, issued in 1943.

1944 Hired as director of the Foreign Nationalities Division, Democratic National Committee. Winter in Key West.

1945 In January, as a result of his service to the Democrats he is informally offered by party officials in Key West the posts of Assistant Secretary of the Treasury and the Post Office Generalship; disenchanted with politics, however, he turns down the offers. Writes the poem "The K." Starts Call Me Ishmael on April 13, finishes by August 6 (the bombing of Hiroshima) all but the introductory chapter on the whaleship Essex, which is written on a boat from Nantucket. Staying at "Enniscorthy," an estate owned by friend Adam Kulikowski near Charlottesville, Virginia, that summer. Returns to Washington (studio at 217 Randolph Place NE). Finishes "This is Yeats Speaking" that November.

1946 On January 4 begins visits to Ezra Pound in St. Elizabeths, which will last until the spring of 1948 (though with at least one visit beyond then). His first poems are published in Harper's Bazaar, Atlantic Monthly, and Harper's. In New York that spring to work as an agent for Polish interests at the early meetings of the United Nations Security Council. Lectures at the School of Political Action Techniques sponsored by the National Citizens Political Action Committee, Washington, June 26-29.

1947 Spring in Washington; March, Call Me Ishmael is published with the help of Ezra Pound and Caresse Crosby (Pound had sent the book to Eliot who found it "too American" and passed it on). Visit to Gloucester in June, lunch with Alfred Mansfield Brooks, director of the Cape Ann Historical Society: the Maximus Poems conceived. Leaves for West Coast on July 2, lecturing on poetry August 8 at the Pacific Northwest Writer's Conference at the University of Washington, Seattle. Goes from there to Sacramento and the Bancroft Library, Berkeley, for Sutter-Marshall and Donner Party material. Meets Robert Duncan and Carl Sauer.

1948 Returns from California to Washington, D.C. by early spring. Writes book on his father composed of three stories, 
"Stocking Cap," "Mr. Meyer," and "The Post Office." Awarded second Guggenheim Fellowship for a book on the morphology of American culture to be called "Red, White \& Black," a study of the differing ways the Indian, white settler, and Negro found to shape a human society in the American West. Writes "The Fiery Hunt," a dance-play based on Moby-Dick. Last political activity, supporting the nomination of Sen. Claude Pepper of Florida for President at the Democratic National Convention that July. Gives lecture on art at American University, Washington, July 29. Invited to Black Mountain College in September by Josef Albers; gives three lectures, asked to return one week out of every month to replace Edward Dahlberg (through the spring of 1949).

1949 His first collection of verse, $Y \mathcal{} \cup$, is published in February, through Cagli's suggestion, by Caresse Crosby's Black Sun Press. "The Kingfishers" written in Washington, FebruaryMarch (final draft dated Black Mountain, 20 July). Reads at the Institute of Contemporary Art, Washington. Summer at Black Mountain; directs "Exercises in Theatre," August 28-29. Fall in Washington, writing. Seeks out Vincent Ferrini while on a visit to his mother in Gloucester, having read a poem by him in Imagi. Lectures at the Watkins Gallery, American University, December 15, to open an exhibit of "Drawings in the 4th Dimension" by Corrado Cagli.

1950 First Maximus poem "I, Maximus of Gloucester, to You," written that May in Washington as a letter to Vincent Ferrini. Ferrini sends some of Olson's poems to Robert Creeley, then planning a little magazine in New Hampshire, but Creeley turns the poems down, writing Ferrini that Olson is "looking around for a language, and the result is a loss of force." Olson responds to Creeley's rejection, and their correspondence, which will grow to an exchange of: almost 1,000 letters all together, begins. April-May, takes the Cagli exhibit on the road (with a stop at Montevallo, Ala., enroute, to visit the author Robert Payne) to Black Mountain, where he repeats his Washington lecture and gives a reading. Returns to Washington. "Projective Verse" is published in Poetry New York in October. Mother dies in Worcester on Christmas Day. 
1951 February to July in Lerma, Campeche, on the Yucatan peninsula; meanwhile Origin 1, featuring Olson, has appeared in April. Returns to Black Mountain at the invitation of the students, teaches through August (will remain as a faculty member, and later rector, until the closing of the school in 1956). Daughter Katherine Mary born October 23.

1952 Spring, receives grant for study of Mayan glyphs from the Wenner-Gren Foundation for Anthropological Research. Fall in Washington, on leave of absence from Black Mountain.

1953 In Cold Hell, In Thicket published by Creeley in Mallorca in March. Organizes an Institute of the New Sciences of Man, held at Black Mountain, March 7-28. First major run of Maximus poems, from Letters 5 on, also begun in March. Reads Maximus letters $1-10$ and 11-22 for the first time, at Black Mountain in August. The Maximus Poems / 1-10 published in Stuttgart by Jonathan Williams in October.

1954 Mayan Letters published in January. Meets Elizabeth Kaiser, a student at Black Mountain, who is to be his wife. Reads at the Charles Street Meeting House, Boston, September 11.

1955 Son Charles Peter born May 12.

1956 Writes "As the Dead Prey Upon Us," "The Lordly and and Isolate Satyrs," and "Variations Done for Gerald Van De Wiele." Closes Black Mountain in October; remains with wife and son, preparing the property for sale. Appointed by the court, assignee for benefit of the creditors of Black Mountain. The Maximus Poems / 11-22 published that fall.

1957 Writes "The Librarian." That February gives readings at the San Francisco Museum of Art, the Poetry Center of San Francisco State College, and at Carmel Highlands; offers "A Special View of History" in five lectures for private subscribers. Returns to Black Mountain, and by June sells the property. In July moves with family to 28 Fort Square, Gloucester. Second run of Maximus poems begun late that fall with "a Plantation a beginning."

1958 Living in Gloucester, except for a period from June to November at Provincetown.

1959 "Maximus from Dogtown-I" written that fall. 
1960 Reads at Wesleyan Spring Poetry Festival, April 19 (the first of his collegiate readings that will include Brandeis, Dartmouth, Goddard, Cornell, St. Lawrence, Brown, and later, Buffalo and Tufts). Reads April 30 in Toronto. The New American Poetry published in May, The Maximus Poems and The Distances in November. Reads at Hammond's Castle, Gloucester, September 3. Participates in Timothy Leary's research program on consciousness-altering drugs in Cambridge in late November, and again in January 1961.

1961 Receives Longview Foundation award for The Maximus Poems.

1962 February, reads at Magnolia, Mass.; gives Morris Gray reading at Harvard; reads again in Toronto. Summer in New York for six weeks, visiting with LeRoi Jones and Edward Dorn.

1963 Attends the Vancouver Poetry Conference, July 29August 16, where he reads the whole of Maximus $I, V, V I$. Assumes duties as Visiting Professor of English, State University of New York at Buffalo, that September, teaching courses in Modern Poetry and Myth and Literature, and living in Wyoming, N.Y., some 40 miles southeast of Buffalo.

1964 Wife killed in an automobile accident in Batavia, N.Y., March 28. Spends summer in Gloucester. Returns to Buffalo in September to teach until May 1965.

1965 Reads at the Festival of the Two Worlds, Spoleto, June 26 to July 2. Attends PEN conference in Bled, Yugoslavia. Reads and gives seminar at the Berkeley Poetry Conference, July 20-23. Human Universe and Other Essays published in a limited edition in August. Awarded Poetry magazine's Oscar Blumenthal-Charles Leviton Prize. Returns to teach at Buffalo in September, but after two weeks returns to Gloucester.

1966 Leaves Gloucester for London in October (will stay until February 1967). Reads for the Literarisches Colloquium at the Akademie der Kunstes, Berlin in December; suffers minor coronary attack some days later.

1967 Selected Writings published in March. Leaves London that month for Dorchester, England, to do research among the Weymouth Port Books on the early settlers of Gloucester. 
lxvi

Chronology

Returns to London, reads at the International Poetry Festival, July 12. Flies back to Gloucester. Addresses the State University of New York Convocation in the Arts, Cortland, N.Y., October 20-22.

1968 Lectures and reads at Beloit College, March 25-29. Visits Donald Allen in San Francisco and Drummond Hadley in Tucson, returning to Gloucester in May. The Maximus Poems IV, V, VI published in London on November 28.

1969 In September visits Charles Boer in Connecticut and in October accepts the post of Visiting Professor at the University of Connecticut. Letters for Origin published in September. Shortly after Thanksgiving, admitted to Manchester (Conn.) Hospital; transferred to New York Hospital.

1970 Dies in New York, January 10, of cancer of the liver. 